\title{
BASELINE STUDY KESETARAAN GENDER DI UIN MALANG
}

Oleh: Mahpur

\section{Dosen Psikologi UIN Malang}

ABSTRACT

Keberhasilan pembangunan dan keberhasilan dalam menjalani proses historis kehidupan dalam semua tingkatan akan sangat tergantung pada peran serta laki-laki dan perempuan secara bersamaan sebagai pelaku dan pemanfaatnya. Ketidakseimbangan serta peminggiran terhadap peran serta dari salah satu elemen tersebut bisa berakibat pada ketimpangan dan ketidakadilan. Oleh karena itu, semua program pemberdayaan harus memperhatikan dan diorientasikan pada pencapaian dan optimalisasi peran yang setara antara laki-laki dan perempuan dalam berbagai aspek kehidupan sehingga mampu mendorong kearah perubahan sosial dalam pembangunan. Salah satu wacana yang menawarkan perpektif kesetaraan dan keadilan gender dalam proses percepatan pembangunan adalah wacana gender. Yaitu, suatu keadaan yang memberikan peluang kesamaan kondisi bagi laki-laki dan perempuan untuk memperoleh kesempatan dan hak-haknya sebagai individu untuk berpartisipasi dalam seluruh aspek kehidupan serta menikmati hasil-hasil pembangunan. Dengan perspektif kesetaraan gender, diharapkan semua sumber daya manusia baik laki-laki dan perempuan dapat berperan secara optimal dalam proses pembangunan. Untuk menuju cita-cita tersebut, maka dibutuhkan suatu komitmen bersama dari berbagai pihak di berbagai sektor disamping upaya-upaya lain yang bersifat kultural.

Di Indonesia, pengarusutamaan gender (gender mainstreaming) saat ini merupakan salah satu agenda yang harus dilaksanakan di berbagai aspek dan suatu keharusan bagi setiap penentu kebijakan untuk melaksanakan program -program strategis dari mulai perencanaan, pelaksanaan, pemantauan dan evaluasi untuk menerapkan pengarusutamaan gender dengan memasukkan wawasan gender sesuai dengan kewenangan dan fungsi masing-masing termasuk melaksanakan gender mainstreaming di lingkungan dibawah wewenangnya.

Lebih jauh lagi, isu gender dan pembangunan sangat penting untuk dihubungkan dengan proses pendidikan dan lembaga pendidikan itu sendiri. Hal ini mengacu pada tiga alasan mendasar. Pertama, lembaga pendidikan adalah wadah institusional dimana semua pegawai (laki-laki dan perempuan) mengekspresikan segala potensinya, mengaktualisasikan dan mendefinisikan identitas dirinya. Kedua, lembaga pendidikan merupakan institusi dinamis yang menyiapkan, memproduksi dan mengembangkan potensi sumberdaya manusia. Ketiga, lembaga 
pendidikan mereproduksi ideologi atau doktrin tertentu, baik melalui kebijakan atau via inkulturasi atmosfer kerja. Melalui proses pendidikan, nilai-nilai diperkenalkan, ditransmisikan dan ditransformasikan. Akibatnya, proses pendidikan-pengajaran dan lembaga pendidikan (khususnya lembaga pendidikan perguruan tinggi) memainkan peranan penting dalam menggariskan dan merealisasikan arah pembangunan, terutama sebagai tolak ukur untuk melihat apakah pembangunan melahirkan keadilan gender baik pada tataran penyiapan sumber daya manusia atau perlakuan pada sumber daya manusia (karyawan dan mahasiswa) yang ada itu sendiri.

Konsep pengarusutamaan gender dalam konteks perguruan tinggi Agama Islam seperti IAIN/UIN/STAIN, merupakan sebuah gagasan yang menantang dan tidak mudah mengingat wacana gender sendiri mendapat persepsi dan respon yang berbeda dari kalangan akademisi (civitas akademika). Pada dasarnya sebagai sebuah lembaga formal pendidikan yang berbasis keagamaan, UIN, IAIN dan STAIN memiliki kekuatan strategis untuk memproduksi dan mengembangkan paradigma baru yang dapat disebarluaskan dengan melibatkan seluruh elemen di dalamnya (stakeholders). Proses ini jika ditarik pada konteks yang lebih jauh lagi akan turut menyokong lahirnya masyarakat madani yang menekankan pada prasyarat utamanya yaitu terciptanya akses dan kesempatan yang luas bagi siapapun tanpa memandang jenis kelamin, golongan, suku maupun agama.

UIN Malang merupakan bagian dari agen perubahan sosial. Oleh karena itu diharapkan bahwa disamping menjalankan fungsinya dalam bidang pengembangan dan penerapan ilmu pengetahuan, UIN Malang diharapkan mampu melaksanakan dekonstruksi nilai sosial budaya yang terkandung didalamnya termasuk nilai-nilai relasi gender. Usaha tersebut dapat dilaksanakan melalui kegiatan membangun sikap sensitif gender dikalangan civitas akademika, dan menerapkan strategi pengarusutamaan gender.

Terkait dengan persoalan diatas, ada beberapa persoalan penting untuk diketahui terutama dalam konteks pemberdayaan perempuan melalui media pengarusutamaan gender dilingkungan UIN Malang. Pertama, apakah proses penyelenggaraan pendidikan di UIN Malang memperlihatkan realitas pembangunan yang berkeadilan gender? Kedua, apa visi dan misi UIN Malang serta acuan dasar hukum (statuta) yang dijadikan pijakan pembuatan kebijakan untuk menyelenggarakan pendidikan di UIN Malang? Keempat, apakah proses pendidikan di UIN Malang bergerak kearah semangat sosialisasi nilai dan gagasan yang memperjuangkan 
kesetaraan relasi gender? Keenam, bagaimana tanggapan civitas akademika UIN Malang, terutama pada jajaran pimpinan terhadap usaha pengarusutamaan gender?

Berdasarkan pemikiran diatas, maka dipandang perlu untuk mengadakan penelitian untuk melihat potret profil atau peta kondisi objektif relasi gender yang ada di lingkungan UIN Malang sebagai acuan rancang bangun instrumen pembangunan dan mengevaluasi tingkat perkembangan partisipasi, dan kontribusi seluruh komponen civitas akademika UIN Malang dalam proses terciptanya pengarusutamaan gender. Oleh karena itu, baseline study ini didesain untuk mencermati bagaimana konsep, realitas dan strategi pengarusutamaan gender di lingkungan UIN Malang untuk refleksi dan menata ke depan. permasalahan yang dapat dirumuskan dalam penelitian ini yaitu, pertama, Apa acuan dasar yang dijadikan pijakan pembuatan kebijakan untuk penyelenggaraan pendidikannya?; kedua, Apakah proses penyelenggaraan pendidikan di UIN Malang memperlihatkan realitas pembangunan yang berkeadilan gender dengan melihat indikator distributor civitas akademika (dosen, pegawai dan mahasiswa) menurut variabel gender , tingkat pendidikan, jabatan fungsional, pangkat struktural dan golongan?; ketiga, Apa dan bagaimana strategi yang dikembangkan UIN Malang untuk mendorong agenda pengarusutamaan gender?

Sesuai dengan rumusan masalah tersebut, maka penelitian ini bertujuan untuk: pertama, untuk mendapatkan gambaran acuan dasar pembuatan kebijakan penyelenggaraan pendidikan dalam perspektif pengarusutamaan gender. Kedua, untuk melihat kondisi objektif dari realitas kesetaraan gender di UIN Malang. Ketiga, untuk melihat Strategi kebijakan untuk mendukung arah model geliat pembangunan yang mendorong agenda pengarusutamaan gender di lingkungan UIN Malang.

Adapun sigifikansi dari diadakannya penelitian ini adalah; pertama, studi ini diharapkan dapat memberikan kontribusi penting kearah peningkatan kualitas pembangunan yang lebih berkeadilan gender melalui agenda pengarusutamaan gender. Kedua, data dan informasi tentang kondisi dan realitas potensi relasi gender di UIN Malang dapat dijadikan dasar pengambilan kebijakan untuk mencapai pembangunan yang berkesetaraan gender terutama dalam lingkup pendidikan.

\section{LANDASAN TEORI}

\section{Konsep Seks dan Gender}


Istilah gender dibedakan dari istilah Seks. Istilah gender merujuk kepada perbedaan karakter laki-laki dan perempuan berdasarkan konstruksi sosial budaya, yang berkaitan dengan sifat, status, posisi dan perannya dalam masyarakat. Gender dipahami sebagai suatu konsep mengenai peran laki-laki dan perempuan dan laki-laki di suatu masa dan kultur tertentu. Peran tersebut dipelajari dan dikonstruk dari waktu kewaktu yang berbeda yang memungkinkan terjadinya perubahan. Apabila watak budaya yang melingkupinya berubah, maka peran dan status gender dari laki-laki dan budaya juga bisa berubah. Dengan demikian, gender berkaitan dengan bagaimana kita diharapkan untuk berfikir dan bertindak sebagai laki-laki dan perempuan sesuai dengan apa yang diharapkan masyarakat dan kekuasaan yang ada.

Sedangkan istilah seks merujuk kepada perbedaan jenis kelamin laki-laki dan perempuan secara biologis terutama yang terkait dengan prokreasi dan reproduksi. Laki-laki dicirikan dengan adanya sperma dan penis serta perempuan dicirikan dengan adanya sel telur, rahim, vagina dan payudara. Ciri jenis kelamin tersebut bersifat bawaan, permanen, dan tidak dapat dipertukarkan sebagai kodrat Tuhan yang tidak mengalami perubahan dengan konsekuensikonsekuensi logisnya.

Perbedaan gender yang juga disebut sebagai perbedaan jenis kelamin secara sosial budaya terkait erat dengan perbedaan secara seksual, karena dia merupakan produk dari pemaknaan masyarakat pada sosial budaya tertentu tentang sifat, status, posisi, dan peran lakilaki dan perempuan dengan ciri-ciri biologisnya. Laki-laki dianggap mempunyai sifat kuat dan tegas, menjadi pelindung bertugas mencari nafkah dan menjadi pemilik dunia kerja (publik), dan sebagai orang pertama. Sedangkan perempuan dianggap bersifat lemah sekaligus lembut, perlu dilindungi, mendapat pembagian tugas sebagai pengasuh anak dan tugas domestik lainnya serta dianggap sebagai orang nomor dua (Fakih, 1996:7). Karena sifat dan peran gender merupakan produk dari konstruk sosial budaya maka bersifat tidak permanen dan dapat dipertukarkan.

Perbedaan gender tidak menjadi masalah ketika tidak menjadi persoalan sosial budaya, yaitu adanya ketidaksetaraan gender yang kemudian menghasilkan berbagai bentuk ketidakadilan dan penindasan terhadap warga masyarakat dengan jenis kelamin tertentu biasanya perempuan (Putra, 2001:6). Namun pada kenyataannya perbedaan gender telah melahirkan berbagai ketidakadilan, bukan saja kepada perempuan tetapi juga kepada laki-laki. Ketidakadilan tersebut mengakibatkan salah satu jenis kelamin mengalami diskriminasi. 
Ketidakadilan gender yang biasanya menimpa pada perempuan bermula dari adanya kesenjangan gender dalam berbagai aspek kehidupan, terutama dalam hal akses terhadap pendidikan dan sumber ekonomi. Hal ini dapat disebabkan karena adanya pelabelan negatif bahwa perempuan adalah lemah, yang juga bisa bermula dari adanya mitos-mitos yang terbangun dalam suatu masyarakat. Misalnya mitos tentang sperma sebagai inti kehidupan. Perempuan tidak mempunyai inti kehidupan, mampunya hanya menerima, maka perempuan adalah manusia nomor dua dan lemah (Subhan, 1999:33).

Ketidakadilan gender yang banyak menimpa perempuan termanifestasikan dalam beberapa bentuk yaitu stereotipi, subordinasi, marjinalisasi, beban ganda, dan kekerasan (Fakih, 1996:10). Manifestasi ketidakadilan tersebut masing-masing tidak dapat dipisahkan, saling terkait dan berpengaruh secara dialektis.

Adanya studi gender pada dasarnya bertujuan untuk mengurangi dan menghilangkan ketidakadilan gender tersebut. Dengan kata lain, studi gender hendak mewujudkan keadilan sosial, dan keadilan sosial tidak dapat diwujudkan tanpa adanya keadilan gender dalam masyarakat. Keadilan gender biasanya merujuk pada aplikasi keadilan sosial dalam hal pemberian kesempatan yang sama antara laki-laki dan perempuan. Keadilan di sini tidak berarti bahwa laki-laki dan perempuan adalah sama dalam segala hal, namun yang dimaksud adalah bahwa pemberian suatu kesempatan atau akses tidak tergantung pada perbedaan jenis kelamin. Keadilan gender, dengan demikian, dapat diartikan bahwa laki-laki dan perempuan memiliki dan menikmati status yang sama. Laki-laki dan perempuan sama-sama memiliki kesempatan untuk merealisasikan hak-hak dan potensinya untuk memberikan kontribusi pada perekembangan politik, ekonomi, sosial, dan budaya, serta sama-sama dapat menikmati hasil dari perkembangan itu. Oleh karena itu, dalam studi gender digunakan analisis gender yang merupakan pengkajian pembagian kerja yang berbasis jenis kelamin, akses dan kontrol yang dimiliki laki-laki dan perempuan.

\section{Konsep Pengarusutamaan Gender}

Pengarusutamaan gender adalah suatu strategi untuk mencapai kesetaraan dan keadilan gender melalui perencanaan dan penerapan kebijakan yang berperspektif gender pada organisasi dan institusi. Pengarusutamaan gender merupakan strategi alternatif bagi usaha pencepatan tercapainya kesetaraan gender karena nuansa kepekaan gender menjadi salah satu landasan 
dalam penyusunan dan perumusan strategi, struktur, dan sistem dari suatu organisasi atau institusi, serta menjadi bagian dari nafas budaya di dalamnya.

Pengarusutamaan gender adalah strategi alternatif untuk melengkapi dua strategi terdahulu, Women in Development (WID) dan Gender and Development (GAD) dan dideklarasikan semenjak tahun 1995 pada Forth World Conference on Women di Beijing (Fakih, 1999:13). WID sebagai strategi pertama popular pada 1975-1985 ketika tahun-tahun itu dideklarasikan oleh PBB sebagai "Dasawarsa PBB untuk Perempuan" (Saptari dan Halzner, 1997:154). Sejak saat itu, hampir semua pemerintahan dunia ketiga mulai mengembangkan Kementerian Peranan Wanita, dengan fokus utama meningkatkan peran wanita dalam pembangunan. Strategi peningkatan peran wanita dalam pembangunan ini didasarkan pada suatu analisis yang lebih memfokuskan pada kaum perempuannya. Strategi ini dibangun di atas asumsi bahwa permasalahan kaum perempuan berakar pada rendahnya kualitas sumber daya perempuan itu sendiri yang menyebabkan mereka tidak mampu bersaing dengan kaum laki-laki dalam masyarakat termasuk dalam pembangunan.

Strategi kedua muncul dengan lebih memfokuskan pada sistem, struktur, ideologi, dan budaya hidup masyarakat yang melahirkan bentuk-bentuk ketidakadilan yang dikenal dengan ketidakadilan yang bersumber pada keyakinan gender. Bagi strategi kedua ini letak persoalannya bukanlah pada kaum perempuan sebagaimana diasumsikan semula, akan tetapi pada bagaimana menghapuskan segala bentuk diskriminasi dan ketidakadilan gender. Strategi kedua ini menitikberatkan pada pemberdayaan (empowerment) dan perubahan struktur gender inilah yang dikenal dengan pendekatan Gender and Development (GAD). Berbeda dengan WID yang melahirkan proyek-proyek peningkatan peran perempuan seperti proyek peningkatan penghasilan perempuan dan didirikannya kementerian peranan wanita, maka puncak keberhasilan strategi kedua ini menghasilkan kebijakan global yang monumental bagi perjuangan kaum perempuan ini, yakni dengan diterimanya secara global konvensi anti segala bentuk diskriminasi terhadap kaum perempuan yang dikenal dengan CEDAW (Convention on the Elemination of all Form of Discrimination Againts Women) tersebut.

Selanjutnya dalam konferensi Nairobi tahun 1985 gender dibicarakan upaya mengurangi praktek diskriminasi terhadap perempuan yang kemudian melahirkan strategi ketiga yang dikenal 
dengan istilah Strategi Gender Mainstreaming yang merupakan pematangan dari GAD yang tujuan dasarnya menjadikan gender sebagai arus utama dalam pembangunan.

Strategi ini muncul sebagai sebagai strategi alternatif dari strategi-strategi sebelumnya yang mencita-citakan percepatan terciptanya keadilan gender di masyarakat. Strategi ini menggunakan sarana advokasi dan perencanaan kebijakan. Untuk melihat apakah strategi gender mainstreaming sudah diterapkan atau tidak, gender scan adalah salah satu instrumen yang dapat dipakai sebagai langkah strategis.Akses dan kontrol terhadap SDM dalam organisasi, sensitifitas gender dalam pengembangan perencanaan dan kebijakan organisasi, adanya kebutuhan strategis gender (gender need), kesamaan gender di organisasi dan pembagian kerja berdasarkan gender merupakan perangkat yang terdapat dalam gender scan.

Selanjutnya ada beberapa langkah yang bisa dilakukan dalam upaya menjadikan gender sebagai mainstream dari sebuah organisasi, yaitu (Muawanah dan Hidayah, 2006:18):

1. Menjadikan kesetaraan gender sebagai misi organisasi

2. Menerjemahkan misi ke dalam tujuan dan sasaran yang operasional dan mengaplikasikan tujuan ke dalam program organisasi dan program sosial yang sensitif gender

3. Mengembangkan pola yang sensitif gender

4. Mengembangkan pola hubungan antar individu di organisasi dan dengan individu luar organisasi yang sensitif gender

5. Mencegah adanya atribut-atribut gender dalam komunikasi organisasi

6. Membebaskan sistem pembagian kerja perempuan dan laki-laki yang bias gender

7. Menciptakan aturan-aturan yang melindungi anggota organisasi (terutama perempuan) dari praktek-praktek diskriminasi, kekerasan, pelecehan yang berlatar belakang gender

8. Mendayagunakan SDM organisasi untuk mendukung upaya kesetaraan gender

9. Menciptakan jaringan dan kolaborasi dengan lingkungan luar sehingga upaya sehingga upaya kesetaraan dimasyarakat dapat berlangsung secara integratif 
Langkah-langkah diatas dapat dilakukan untuk menudukung berhasilnya strategi gender mainstreaming untuk menciptakan kesetaraan antara laki-laki dan perempuan dalam masyarakat melalui organisasi

\section{Organisasi dan Gender}

\section{Gender dan Perubahan Organisasi}

Perubahan adalah tuntutan natural bagi tegak dan kelestarian suatu organisasi atau institusi. Sebagai sistem organisasional yang terbuka, terutama semenjak dekade 1990, suatu organisasi berada di lingkungan global yang selalu berubah secara dinamik. Salah satu faktor yang mendorong untuk berubah adalah meningkatnya kuantitas dan kualitas angkatan kerja perempuan dalam setiap organisasi, yang diiringi adanya tuntutan perubahan perspektif dalam memandang pekerja perempuan sebagai bagian dari organisasi tersebut (Robbins, 1998:537).

Perubahan organisasi tidak terjadi dengan sendirinya, melainkan melalui proses belajar. Berusaha untuk selalu mengembagkan diri sehingga mempunyai kapasitas untuk beradaptasi dengan perbahan-perubahan lingkungannya adalah proses belajar. Tuntutan kesetaraan gender merupakan salah satu dari banyak tuntutan perubahan secar global. Perubahan organisasi harus meliputi semua unsur dalam organisasi, yaitu strategi (sasaran-sasaran organisasi dan cara-cara yang ditempuhnya untuk mencapainya, struktur (pengelompokan dan pembagian tugas-tugas, wewenang, serta tanggung jawab, posisi-posisi relatif dan hubungan-hubungan formal antar anggotanya, sistem (syarat-syarat dan kesepakatan-kesepakatan yang berkaitan dengan tata cara, dan budaya (perpaduan atau penjumlahan pendapat-pendapat perorangan, nilai-nilai yang dianut bersama, norma-norma yang diikuti oleh para anggotanya). Dalam proses perubahan organisasi, keempat unsur tersebut bergerak saling kait mengkait. Apabila terjadi perubahan pada salah satu unsurnya maka perubahan itu akan bergerak mempengaruhi unsur yang lain. Namun apabila menyangkut perubahan perspektif maka kebanyakan teoritisi sepakat bahwa perubahan harus dimulai pada tingkat budaya organisasi.

Akan tetapi dalam dunia manajemen dan administrasi pada umumnya masih mempertahankan tradisi divisi kerja secara seksual yang menempatkan perempuan pada pekerjaan yang menawarkan sisi feminitas perempuan seperti keramahan, kepedulian dan kelembutannya dan bukan pada ketelitiannya. Suatu posisi yang ukan merupakan posisi 
pemegang kunci kebijakan organisasi. Realitas ini sudah menjadi suatu fenomena global dari posisi suatu jenis kelamin tertentu, yang dalam hal ini kebanyakan kaum perempuan, dalam organisasi, administrasi dan manajemen modern. Hal ini juga menjadi bagian yang menarik diaktualisasikan di lingkungan UIN Malang.

\section{Organisasi Sensitif Gender}

Suatu organisasi merupakan gambaran dari lingkungan sosial budayanya ketika organisasi tersebut dibangun. Apabila suatu organisasi dibangun pada masa dimana lingkungan sosial budaya yang melingkupinya masih bersikap salah satu jenis kelamin tertentu dan mendeskreditkan jenis kelamin yang lain, maka akan sangat mungkin jika organisasi yang dibangun tersebut tidaklah netral gender. Misalnya, suatu organisasi yang lebih mengedepankan laki-laki sebagai pimpinan yang berakibat pada pada keputusan-keputusan yang dibuat dan arah jalannya organisasi mereflesikan perspektif laki-laki saja dan mengabaikan perspektif perempuan. Dalam pembagian tugas, organisasi tersebut menempatkan laki-laki pada urusanurusan yang bersifat publik sedangkan perempuan ditempatkan pada urusan yang bersifat domestik seperti bendahara, sekretaris dan resepsionis. Kondisi yang sudah terbentuk seperti itu seringkali tidak disadari sebagai suatu persoalan karena telah berlangsung lama. Oleh karena itulah, untuk merubah membangun serta merubah suatu organisasi yang peka gender perlu adanya upaya sistematis secara sadar pada seluruh komponen yang terlibat di dalam organisasi tersebut.

Suatu organisasi yang sensitif gender adalah suatu organisasi yang memiliki struktur dan budaya organisasi yang peka gender. Dalam organisasi yang peka gender, perempuan dan lakilaki diposisikan secara setara dan budaya organisasi beroperasi secara setara bagi laki-laki dan perempuan, hasil kerja laki-laki dan perempuan dinilai setara dan interaksi sosial yang dibangun antara laki-laki dan perempuan juga merefleksikan penghormatan dan penghargaan terhadap kedua jenis kelamin yang berbeda tersebut. Laki-laki dan perempuan dapat dan akan bekerja bersama dalam mencapai keberhasilan organisasi.

Ada beberapa aspek kunci yang harus diperhatikan dalam membangun organisasi yang sensitif dan berkesetaraan gender, yaitu (Mcdonald, 1999:126) : 
1. Rupa organisasi dalam arti pembagian kekuasaan untuk mengambil keputusan. Pada umumnya organisasi bersifat patriarkhal yang terefleksikan pada posisi-posisi tertinggi dan penting diduduki oleh laki-laki. Rumusan -rumusan dan kebijakan yang dihasilkan sangat memungkinkan bias gender. Akan tetapi, faktor utama tidak hanya pada posisi laki-laki sebagai pimpinan akan tetapi sensitifitas gender yang dimiliki oleh pimpinan tersebut. Pimpinan perempuan juga bisa merumuskan kebijakan yang bias gender apabila pimpinan tersebut tidak memiliki sensitifitas gender.Oleh karena itu, selain pembagian kekuasaan yang proporsional antara laki-laki dan perempuan pada tingkat kepemimpinan juga diperlukan adanya kesadaran dan sensitifitas gender (gender awareness dan gender sensitivity) pada pribadi-pribadi pimpinan dalam suatu organisasi yang mampu mengabsorsi dan merumuskan kebijakan yang netral gender bagi seluruh stafnya.

2. Keseimbangan antara staf perempuan dengan staf laki-laki khususnya dalam dalam posisi manajer dan peran-peran penentu kebijakan. Organisasi yang tidak memiliki keseimbangan komposisi pada umumnya akan melahirkan kebijakan yang bias gender. Misalnya, suatu organisasi yang didominasi oleh laki-laki mendorong munculnya sikapsikap patriarkhis sebagaimana yang terserap dari masyarakatnya. Fenomena pemarjinalan pada pekerja perempuan juga bisa terjadi seperti pemberian tanggung jawab pada pekerjaan yang tidak berkualitas dan bersifat publik dikarenakan kekhawatiran yang bersifat biologis dan kadangkala bias gender.

3. Budaya dan gaya organisasional. Budaya dan gaya organisasi yang bias gender membentuk perempuan untuk tidak bisa melepaskan diri dari kehidupan pribadi pada saat ditempat kerja sedang laki-laki dibentuk menjadi pribadi pekerja yang tidak memikirkan kehidupan pribadi dan bekerja seperti mesin. Oleh karena itu perlu diupayakan perubahan budaya dan gaya organisasi yang ramah gender sehingga tidak merugikan kedua jenis kelamin.

4. Kinerja sehari-hari apakah ramah terhadap perempuan atau bahkan ramah terhadap semua orang. Menurut McDonald, ada sebelas karakteristik yang dimiliki oleh organisasi yang ramah gender sebagai berikut (Mcdonald, 1999:138):

Tersedianya prasarana yang memadai, misalnya kamar mandi untuk perempuan, prasarana pengasuhan anak, dan sarana pengangkutan yang aman. Kemudian bahan-bahan pajangan di dalam gedung kantornya seprti poster-poster, foto-foto, tulisan-tulisan, termasuk pengumuman tentang rapat staf dan kegiatan-kegiatan organisasi tidak melecehkan atau tidak menghormati perempuan.

Laki-laki maupun perempuan tidak membuat lelucon atau melontarkan lelucon atau komentar yang merendahkan satu sama lain. Apabila terjadi kasus pelecehan seksual, organisasi sudah memiliki tatacara penanganannya

Perbedaan gaya kerja laki-laki dan perempuan tidak dianggap sebagi kendala kemajuan organisasi, sebaliknya dipandang sebagai kekuatan organisasi

$>$ Pengaturan-pengaturan kerja yang ada memungkinkan perpaduan antara tanggung jawab di luar kantor (reproduktif/pengelolaan rumah tangga) dengan pekerjaan 
kantor, misalnya ada kebijakan tentang kerja paruh waktu, jam-jam kerja tidak kaku, tatacara untuk mendapatkan ijin tidak masuk kerja tidak merepotkan, dsb.

$>$ Kesetaraan gender tidak hanya menjadi prioritas dalam pernyataan misi (atau AD/ART) organisasi, dalam kebijakan dan sasaran-sasarannya, tetapi juga menjadi prioritas dalam pengaturan-pengaturan internal seperti tatacara penerimaan pekerja baru, syarat-syarat kerja, dan lain sebagainya.

Pertanggungjawaban terhadap perempuan harus dimasukkan kedalam kebijakankebijakan tertulis dan dilaksanakan dalam praktik

> Harus ada keseimbangan yang lebih baik dalam jumlah staf laki-laki dan perempuan serta pembagian kerjanya. Lebih penting lagi, staf perempuan khususnya dalam manajemen harus memiliki komitmen terhadap kesetaraan gender

$>$ Cara pengelolaan diatas bukanlah "manajemen feminin", tetapi "manajemen feminis". Arti istilah iniadalah manajemen oleh laki-laki dan perempuan yang berkomitmen pada pemberdayaan perempuan

Lantaran mungkin hanya organisasi yang sangat kecil sajalah yang tidak butuh tatanan berjenjang, maka tingkat perjenjangan tidak bisa tidak harus ada. Meski demikian, harus ada juga manajemen yang terbuka pada arah perubahan, berorientasi pada pelatihan, dukungan, umpan balik yang bermanfaat, serta mendorong kemajuan sesama rekan kerja

Harus ada ruang untuk dan dorongan kearah pembentukan prakarsa-prakarsa dari bawah keatas, serta forum informal yang "mendatar" untuk dialog dan pertukaran gagasan

> Manajemen harus memberi dukungan tanpa syarat kepada tim gender dan anggota staf-staf yang diberi tanggung jawab atas masalah-masalah gender.

Seluruh usaha pengelolaan organisasi menuju sensitifitas dan kesetaraan gender diatas merupakan bagian dari tahapan menyeluruh dari proses perubahan organisasi menuju kesetaraan gender.

\section{METODE PENELITIAN}

\section{Pendekatan dan Jenis Penelitian}

Baseline studi ini adalah studi evaluasi-deskriftif terhadap agenda institusionalisasi gagasan dan aplikasi kebijakan yang terkait dengan usaha pengarusutamaan gender. Sesuai dengan model penelitian tersebut, pola yang relevan untuk studi ini adalah pola konvergensi antara empirisme dan normatif dengan menggunakan model analisis kelembagaan (institusional 
analysis). pendekatan empiris akan memotret realitas pelaksanaan visi dan misi dimasa mendatang. Sedangkan pendekatan normatif berusaha untuk memetakan peraturan perundangundangan yang mengatur masalah mekanisme kebijakan untuk menuju arah serta mencapai target visi dan misi tersebut.

Pendekatan triangulasional juga akan dipakai dalam penelitian ini berdasarkan dua alasan utama. Pertama, kombinasi pendekatan kuantitatif dan kualitatif disinergikan agar hasil penelitian yang dicapai dapat lebih optimal, integratif, kritis dan komprehensif. Kedua, penelitian ini juga menggabungkan model penelitian kepustakaan dan lapangan.

\section{2 .Penentuan Lokasi Penelitian}

Penentuan "UIN Malang" sebagai lokasi penelitian didasarkan pada pertimbangan bahwa UIN adalah mozaik dari berbagai latar pemikiran dan kultur keislaman dan salah satu lembaga pendidikan tinggi yang menyelenggarakan pendidikan dan pembelajaran ilmu-ilmu keislaman yang sarat dengan proses transfer dan transformasi ajaran-ajaran Islam.

\section{Subyek Penelitian}

Dalam penelitian ini, yang menjadi subyek penelitian adalah para civitas akademika di lingkungan UIN Malang. Penarikan sampel dalam penelitian ini tidak menjadi masalah penting karena studi ini adalah studi analisis kelembagaan yang secara khusus berusaha mendiskripsikan visi dan misi UIN, kondisi dan potensi relasi gender dalam konteks agenda dan strategi pengarusutamaan. Seluruh responden, setting interaksi sosial yang diobservasi serta dokumen yang dianalisis diseleksi secara purposif. Responden pejabat dan pimpinan juga dipilih secara purposif. Mereka adalah dekan dan beberapa kepala unit ( ketua PSG dan kepala perpustakaan).

\section{Sumber dan Teknik Pengumpulan Data}

Data-data yang digunakan dalam penelitian ini meliputi data primer dan data sekunder yang berasal dari tiga sumber yaitu dokumentasi, responden dan informan.

Dokumentasi disandarkan terutama pada pusat dokumentasi di UIN Malang, buku tahunan, serta kumpulan peraturan. Data yang terkumpul berupa informasi tentang jumlah SDM laki-laki dan perempuan, peraturan dan kebijakan, serta data akademik, dan kegiatan-kegiatan. 
Informan adalah para pemegang kebijakan di UIN Malang yaitu dekan, dan kepala unitunit. Data yang diperoleh berupa informasi serta pendapat berkaitan dengan implementasi peraturan dan kebijakan serta permasalahan gender di lingkungan UIN Malang. Pengumpulan data dilaksanakan dengan wawancara.

\section{Teknik Pengolahan dan Analisa Data}

Dalam penelitian ini, pengolahan data dilakukan dengan cara memeriksa seluruh data yang terkumpul untuk dipilih dan dipilah berdasarkan sub-sub pokok bahasan dan perumusan masalah. Karena penelitian ini kualitatif, maka analisis datanya bersifat iteratif (berkelanjutan) dan dikembangkan sepanjang program, mulai dari penetapan masalah, pengumpulan data, dan setelah data terkumpulkan kemudian dianalisis dengan analisis isi (content analysis). Di antara syarat teknik analisis ini adalah terpenuhinya syarat obyektivitas, pendekatan sistematis (dengan menggunakan kriteria tertentu sebagai dasarnya) dan generalisasi yang memiliki sumbangan teoritik (Muhadjir, 2002:68).

Analisis data dalam penelitian ini dilakukan secara induktif, yaitu penulis berangkat dari fakta-fakta dan ketentuan-ketentuan yang bersifat khusus kemudian membuat generalisasi analisis sehingga dapat ditarik kesimpulan yang bersifat umum.

Kegiatan analisis data dalam penelitian ini menggunakan tiga tahapan, yaitu reduksi data, penyajian data, verifikasi dan penarikan kesimpulan. Dalam proses reduksi data, peneliti menganalisis bahan-bahan yang telah terkumpul, menyusunnya secara sistematis, dan menonjolkan pokok-pokok permasalahannya. Tahap berikutnya adalah penyajian data. Dalam tahap ini, peneliti menyajikan sekumpulan informasi yang tersusun yang memberi kemungkinan adanya penarikan kesimpulan dan pengambilan tindakan. Data yang telah dipolakan, difokuskan, dan disusun secara sistematis tersebut diambil kesimpulan sehingga makna data bisa ditemukan.

\section{TEMUAN PENELITIAN}

Berdasarkan rumusan masalah, temuan dari penelitian ini dapat dipaparkan sebagai berikut; pertama, dengan status baru sebagai Universitas tujuan umum dari UIN Malang yang dirumuskan lebih rinci pada visi dan misi yang dibangun menunjukkan adanya netralitas gender atau yang disebut dengan gender blind. Perguruan tinggi Islam ini tidak menekankan pembangunan intelektual civitas akademikanya pada salah satu jenis kelamin tertentu. Hal ini bisa dilihat pada penjabaran dari visi dan misi UIN Malang diatas dimana tidak disebutkan jenis kelamin tertentu akan tetapi pada seluruh mahasiswa secara umum. Dengan visi misi yang netral 
gender menjadi suatu peluang bagi UIN Malang sebagai salah satu wadah transfer ilmu bagi masyarakat untuk membantu terlaksananya upaya sosialisasi pengarusutamaan gender baik dalam lingkup internal kampus (seluruh civitas akademika).

Kedua, isu gender masih merupakan isu yang menjadi bagian dari kesadaran personal dan bukan merupakan kesadaran kolektif. Isu -isu sosialisasi gender masih ditekankan pada Pusat Studi Gender dengan penokohan citra PSG sebagi lembaga yang bertanggung jawab pada penyebaran isu-isu gender.

Ketiga, perempuan yang menduduki posisi strategis sangat minim baik pada level pembuat kebijakan maupun tingkat tenaga pengajar dan pegawai. Misalnya, tidak ada pejabat rektorat yang perempuan, dan bahkan persentase angka pejabat perempuan memiliki prosentase yang sangat sedikit dibandingkan dengan pejabat laki laki dengan perbandingan $73,58 \%$ lakilaki dan 26,42 perempuan.

Ada beberapa penjelasan untuk model kecenderungan utama mengenai sedikitnya pejabat perempuan di atas. Pertama, fenomena tersebut erat kaitannya dengan fakta ketimpangan jumlah tenaga administrasi dan erat kaitannya dengan fakta ketimpangan jumlah tenaga administrasi dan edukatif perempuan jika dibandingkan dengan tenaga administrasi dan edukatif laki-laki. Kedua, latar belakang pendidikan maupun kepangkatan dosen maupun tenaga administrasi perempuan lebih rendah dibanding jika dibandingkan dengan dosen dan tenaga administrasi laki-laki. Hal ini dapat dilihat pada tabel penyebaran dosen perfakultas berdasarkan kepangkatan, berdasarkan pendidikan baik pada dosen maupun pada tenaga administrasi. Ketiga, adalah kesulitan khusus yang dialami perempuan dalam masalah kenaikan kepangkatan. Memang kesulitan ini juga dialami oleh pegawai laki-laki, namun bagi pegawai perempuan, kesulitan ini lebih berat.

Keempat, Berbagai upaya yang dilaksanakan oleh UIN Malang untuk merealisasikan kesetaraan gender adalah dengan memberikan peluang yang sama bagi seluruh sivitas akademika baik laki-laki maupun perempuan untuk mendapatkan posisi tertentu di lingkungan UIN Malang seperti yang tercantum secara formal dalam statuta 2005 sebagai acuan dasar pembuat kebijakan pendidikan dan peluang melanjutkan pendidikan ketingkat Master maupun Doktor bagi seluruh dosen sebagai salah satu bentuk affirmatif action untuk terwujudnya kesetaraan gender.

\section{KESIMPULAN}


Strategi pengaruutamaan gender membutuhkan dukungan struktural yang efektif. Karena peran pihak pimpinan baik di tingkat Universitas maupun fakultas sebagai institusi tertinggi sangat dibutuhkan untuk efektifitas daya tekan. Artinya, tanggung jawab kebijakan pengarusutamaan gender sangat penting dipegang oleh pihak rektorat dan Dekanat. Oleh karena itu, pengarusutamaan gender bukan semata-mata tanggung jawab satu institusi sajaseperti Pusat Studi Gender, namun semua elemen bertanggung jawab untuk melakukannya. Strategi ini tidak menghilangkan arti penting dari peran

\section{DAFTAR PUSTAKA}

Mansour Fakih, Analisis Gender dan Transformasi Sosial, (Yogyakarta: Purtaka Pelajar, 1996), h. $7-8$

Heddy Shri Ahimsa Putra, Enam Pemaknaan Gender, Makalah, 2001. h. 6

Zaitunah Subhan, Tafsir Kebencian, Studi Bias Gender dalam Tafsir Quran, Yogyakarta: LKiS, 1999, h. 33

Mansour Fakih, Analisis Gender dan Transformasi Sosial, h. 10

Mansour Fakih, "Gender Mainstreaming Strategi Mutakhir Gerakan Perempuan" dalam Gender dan Perubahan Organisasi, Menjembatani Kesenjangan Antara Kebijakan dan Praktek, Terj. Omi Intan Naomi, (Yogyakarta: INSIST, 1999), h. xxxiii

Ratna Saptari \& Brigitte Halzner, Perempuan Kerja dan Perubahan Sosial, (Jakarta: Pustaka Utama Grafiti, 1997), h. 154

Elfi Muawanah dan rifa Hidayah,Menuju kesetaraan gender (Malang: Kutub Minar, 2006), h.1819

S.P. Robbins, at.al., Organisational Behavior, (Sydney: Prentice Hall, 1998), h. 537

Mandy Mcdonald, et all, Gender dan perubhan organisasi, Menjembatani kesenjangan Antara Kebijakan dan praktek, diterjemahkan oleh Inatan Naomi (Yogyakarta: INSIST, 1999)h. 126

ibid,h.138-139

Noeng Muhadjir. Metode Penelitian Kualitatif. Yogyakarta: Rake sarasin, 2002, 68-69. 